\title{
An unwanted intruder
}

\author{
F. F. Gonçalves (D) · L. F. Seca · J. I. Moreira
}

Published online: 11 May 2020

(c) The Author(s) 2020

\section{Answer}

While suspecting a thromboembolic event and in order to restore adequate coronary flow, the operator decided to urgently perform manual aspiration, which retrieved an approximately $40-\mathrm{mm}$ structure compatible with radial artery endothelial tissue (Fig. 1). After pre-dilatation with a $2.5 \times 15-\mathrm{mm}$ semi-compliant balloon, a $3.5 \times 23-\mathrm{mm}$ drug-eluting stent was implanted, with no residual stenosis and TIMI grade flow 3 . Radial artery pulse was absent after sheath removal, but distal perfusion to the hand was not compromised.

Radial artery avulsion is a rare complication of transradial access in coronary angiography [1]. Moreover, embolisation of radial endothelial tissue to a coronary artery is an even more unlikely event. Radial avulsion is usually related to sheath withdrawal or spasm with guiding catheter entrapment and vessel trauma caused by its tip [2]. This can be prevented by decreasing artery spasm with careful selection and crossing of guiding catheters, as with intra-arterial administration of vasodilators. Artery avulsion is also more common in small-calibre and tortuous arteries [3]. Preprocedural Barbeau or Allen tests are advisable in order to prevent more serious complications like hand ischaemia.

Conflict of interest F.F. Gonçalves, L.F. Seca and J.I. Moreira declare that they have no competing interests.

Electronic supplementary material The online version of this article (https://doi.org/10.1007/s12471-020-01428-8) contains supplementary material, which is available to authorized users.

\section{F. F. Gonçalves $(\bowtie) \cdot$ L. F. Seca · J. I. Moreira}

Hospital of Vila Real, Cardiology Department, Centro

Hospitalar de Trás-os-Montes e Alto Douro, Vila Real, Portugal

fernando.fonseca.goncalves@gmail.com

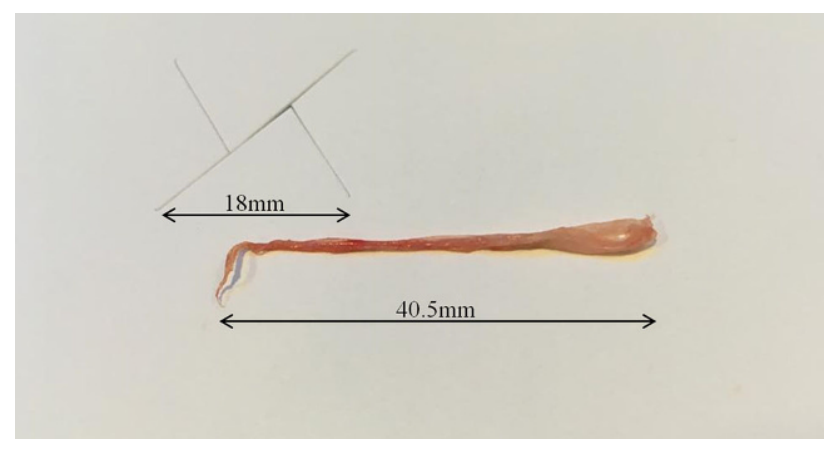

Fig. 1 Endothelial tissue manually aspired from the left obtuse marginal artery

Open Access This article is licensed under a Creative Commons Attribution 4.0 International License, which permits use, sharing, adaptation, distribution and reproduction in any medium or format, as long as you give appropriate credit to the original author(s) and the source, provide a link to the Creative Commons licence, and indicate if changes were made. The images or other third party material in this article are included in the article's Creative Commons licence, unless indicated otherwise in a credit line to the material. If material is not included in the article's Creative Commons licence and your intended use is not permitted by statutory regulation or exceeds the permitted use, you will need to obtain permission directly from the copyright holder. To view a copy of this licence, visit http://creativecommons.org/licenses/by/4.0/.

\section{References}

1. Chugh SK, Chugh Y, Chugh S. How to tackle complications in radial procedures: tip and tricks. Indian Heart J. 2015;67(3):275-81.

2. Dandekar VK, Vidovich MI, Shroff AR. Complications of transradial catheterization. Cardiovasc Revasc Med. 2012;13(1):39-50.

3. Allam VK, Allam AK, Sameeraja V, Pramod MK. Avulsion of radial artery during coronary angiogram-a case report. IHJ Cardiovasc Case Rep. 2017;1(2):80-2. 


\title{
Advertisement placed here.
}

\author{
ces bohn \\ CL van loghum
}

Houten 2021 